\title{
PERAN LEMBAGA KEJAKSAAN UNTUK MENGATASI KENDALA YURIDIS DALAM PENANGANAN PERKARA PELANGGARAN HAM BERAT
}

\author{
Agus Kurniawan', Trynalia², Muhammad Erlangga ${ }^{3}$
}

\begin{abstract}
The State of Indonesia is a state of law as an embodiment of a state of law, this needs to provide guarantees of protection to its citizens and must also maximize the handling of cases of human rights violations which until now have not been resolved where the Prosecutor's Office has juridical constraints in resolving gross human rights violations. Juridical obstacles faced by the Prosecutor's Office in handling serious human rights violations, namely: a) Difficulties of the Prosecutors' Office in Finding Evidence of Human Rights Violations that Occurred in the Past; b) Human Rights Violations Occurred in Indonesia in the Past Before Law Number 26 of 2000 Concerning Human Rights Courts Enacted.

Keywords: Juridical Constraints, Prosecutors' Office, Case of Gross Human Rights Violations

Abstrak

Negara Indonesia adalah negara hukum sebagai perwujudan dari suatu negara hukum ini perlu memberikan jaminan perlindungan kepada warga negaranya dan juga harus memaksimalkan penanganan perkara pelanggaran HAM yang hingga saat ini belum terselesaikan dimana Kejaksaan mempunyai kendala yuridis dalam menyelesaikan pelanggaran HAM berat. Kendala yuridis yang dihadapi oleh Lembaga Kejaksaan dalam upaya penanganan pelanggaran HAM berat, yaitu : a) Kesulitan Lembaga Kejaksaan Dalam Mencari Alat Bukti Pelanggaran HAM Yang Terjadi Di Masa Lalu; b)Pelanggaran HAM Yang Terjadi Di Indonesia Pada Masa Lalu Sebelum Undang-Undang Nomor 26 Tahun 2000 Tentang Pengadilan HAM Diberlakukan.
\end{abstract}

Kata Kunci: Kendala Yuridis, Kejaksaan, Perkara Pelanggaran HAM Berat.

\section{A. Latar Belakang}

Pengakuan dan perlindungan Hak Asasi Manusia meupakan salah satu ciri dari negara hukum. Negara Indonesia merupakan negara yang berlandaskan atas hukum sesuai dengan bunyi Pasal 1 ayat (3) UUD 1945 "Negara Indonesia adalah negara hukum". ${ }^{4}$ Hak Asasi manusia adalah hak dasar atau kewarganegaraan yang melekat pada individu sejak ia lahir secara kodrat yang diberikan langsung oleh Tuhan Yang

\footnotetext{
${ }^{1}$ Program Magister Universitas Veteran Jakarta, agus_kurniawan_sh@yahoo.co.id

2 Program Magister Universitas Veteran Jakarta, cicitrynalia@ymail.com

${ }^{3}$ Program Magister Universitas Veteran Jakarta, m.erlangga912@gmail.com

${ }^{4}$ Rudi Pradisetia Sudirdja, "Implementasi Penegakan dan Perlindungan Hak Asasi Manusia Dalam Konteks Negara Hukum", Negara Republik Indonesia" dimuat dalam http://www. rudipradi setia.com/2010/06/ implementasi-penegakan-dan-perlindungan_21.html, diakses pada tanggal
} 17112019 . 
Maha Esa yang tidak dapat dirampas dan dicabut keberadaannya dan wajib dihormati, dijunjung tinggi, dan dilindungi oleh negara, hukum, pemerintah dan setiap orang demi kehormatan dan perlindungan harkat dan martabat manusia. ${ }^{5}$

Selain itu, Hak Asasi Manusia adalah hak fundamental yang tak dapat dicabut yang mana karena ia adalah seorang manusia. Jack Donnely mendefinisikan hak asasi tidak jauh berbeda dengan pengertian di atas. Hak asasi adalah hak-hak yang dimiliki manusia semata-mata karena ia manusia. Umat manusia memilikinya bukan karena diberikan kepadanya oleh masyarakat atau berdasarkan hukum positif, melainkan semata-mata berdasarkan martabatnya sebagai manusia dan hak itu merupakan pemberian dari Tuhan Yang Maha Esa. ${ }^{6}$

Sementara menurut John Locke, Hak Asasi Manusia adalah hak yang dibawa sejak lahir yang secara kodrati melekat pada setiap manusia dan tidak dapat diganggu gugat. John Locke menjelaskan bahwa HAM merupakan hak kodrat pada diri manusia yang merupakan anugrah atau pemberian langsung dari tuhan YME secara filosofis, pandangan menurut hak asasi manusia adalah, "jika wacana publik masyarakat global di masa damai dapat dikatakan memiliki bahasa moral yang umum, itu adalah hak asasi manusia." Meskipun demikian, klaim yang kuat dibuat oleh doktrin hak asasi manusia agar terus memunculkan sikap skeptis dan perdebatan tentang sifat, isi dan pembenaran hak asasi manusia sampai dijaman sekarang ini. Memang, pertanyaan tentang apa yang dimaksud dengan "hak" itu sendiri kontroversial dan menjadi perdebatan filosofis terus. ${ }^{7}$

Dalam kehidupan masyarakat yang sarat dengan berbagai kepentingan sering terjadi adanya pelanggaran HAM, tindakan menyimpang ini masih sering terjadi pada tiap bangsa/negara. Tidak ada bangsa/negara yang sepi dari kejahatan karena hal ini merupakan fenomena kehidupan manusia. ${ }^{8}$ Hal ini sering merupakan ancaman yang selalu meresahkan masyarakat dan dianggap mengganggu keseimbangan sosial. Eksistensi Hak Asasi Manusia (HAM) dan keadilan merupakan dasar dalam membangun komunitas bangsa yang memiliki kohesi sosial yang kuat. Meskipun banyak ragam ras, etnis, agama, dan keyakinan politik, kita akan dapat hidup harmonis dalam suatu komunitas bangsa/negara, jika ada sikap penghargaan terhadap nilai-nilai HAM dan keadilan. ${ }^{9}$ Eksistensi HAM berbanding lurus dengan keberadaan bangsa, sesuai dengan jangkauan pemikiran dan perkembangan lingkungannya.

\section{${ }^{5}$ Ibid}

${ }^{6}$ Mohammad Wildasite, "Pengertian HAM Atau Hak Asasi Manusia (Human Rights)" dimuat dalam https://mohammadwildasite.wordpress.com/hak-asasi-manusia/, diakses pada tanggal 17112019.

${ }^{7}$ Ibid

${ }^{8}$ Fazlur Rahman, Muhammad Ashri, Trifenny Widayanti, Analisis Yuridis Pelanggaran Hak Asasi Manusia (Ham) Di Indonesia (Studi Kasus Di Mesuji Sumatra Selatan), dimuat dalam http://repository.unhas.ac.id/bitstream/ handle/123456789/4845/JURNAL\%20FAZ.pdf, diakses pada tanggal 18112019.

${ }^{9}$ Ibid 
Untuk itu, setiap kejahatan HAM harus diadili karena kejahatan HAM telah, sedang, dan akan selalu menjadi kendala dalam perjalanan peradaban bangsa. Pelanggaran HAM dapat juga dilakukan oleh satuan nonpemerintah, misalnya pembunuhan penduduk sipil oleh para pemberontak, serangan bersenjata oleh satu pihak kepada pihak lain dan sebagainya. ${ }^{10}$ Terbukti masih banyaknya pelanggaran-pelanggaran HAM berat maupun ringan yang terjadi di Indonesia. Tetapi kita juga tidak bisa menutup mata, jika pada era reformasi ini penegakan HAM di Indonesia sudah menunjukan peningkatan. ${ }^{11}$

Tuntutan terhadap penyelesaian kasus pelanggaran hak asasi manusia telah mendorong lahirnya Undang-Undang Nomor 39 Tahun 1999 tentang Hak Asasi Manusia yang kemudian diikuti oleh Undang-Undang Nomor 26 tahun 2000 mengenai Pengadilan Hak Asasi Manusia yang dimaksudkan untuk menjawab berbagai persoalan pelanggaran Hak Asasi Manusia khususnya pelanggaran hak asasi manusia berat. ${ }^{12}$ Banyak perkara yang telah masuk ke pengadilan hak asasi manusia yang setidaknya terdiri atas 12 perkara pelanggaran hak asasi manusia berat di TimorTimur, 4 (empat) perkara peristiwa Tanjung Priok dan 2 (dua) perkara pelanggaran hak asasi manusia berat di Abepura-Papua tidak menghasilkan keputusan yang memuaskan rasa keadilan khususnya bagi para korban pelanggaran hak asasi manusia berat tersebut. ${ }^{13}$

Terkait dengan berbagai kasus pelanggaran HAM yang terjadi di Indonesia menurut Jaksa Agung RI H.M. Prasetyo berpendapat bahwa : ${ }^{14}$

"Ada kendala yuridis yang kita hadapi dalam proses penegakan hukum. Pelanggaran HAM berat masa lalu, memang harus diselesaikan, tapi ini kasuskasusnya-kan sudah lama sekali meski perkara pelanggaran HAM berat tidak ada daluarsamelihat realitas yang ada, kesulitan yang dihadapi adalah mencari bukti maupun saksi dari kasus tersebut. "Saksinya juga siapa lagi? Kan sudah sekian lama, perkara 65-66 bayangkan mungkin kita belum lahir, pelakunya siapa? Korban di mana? Bukti-bukti lain seperti apa? Sehingga waktu itu kita usulkan untuk diselesaikan dengan pendekatan nonyudisial, rekonsiliasi, itu yang paling mungkin dilakukan,"Kendala lainnya, kasus-kasus itu terjadi sebelum adanya Undang-Undang Nomor 26 Tahun 2000 tentang Pengadilan Hak Asasi Manusia (HAM) yang mengatur peradilan HAM. Proses hukumnya harus melalui keputusan politik DPR dan dibentuk dulu peradilan HAM ad hoc yang saat ini

\footnotetext{
${ }^{10}$ Ibid

${ }^{11}$ Eko Hidayat, "Perlindungan Hak Asasi Manusia Dalam Negara Hukum Indonesia"dimuat dalam https://media.neliti.com/media/publications/56534-ID-none.pdf, diakses pada tanggal 18112019.

${ }^{12}$ Chainur Arrasjid, Dasar-dasar Ilmu Hukum, (Jakarta: Sinar Grafika, 2000), hlm. 14

${ }^{13}$ Eko Hidayat, Op.cit

14 Mahadeva Wahy, "Ungkap Pelanggaran HAM, Kejaksaan Hadapi Kendala Yuridis", dimuat dalam https://www.cendananews.com/2018/06/ungkap-pelanggaran-ham-kejaksaan-hadapikendala-yuridis.html, diakses pada tanggal 18112019.
} 
belum ada.Persoalan selanjutnya, untuk pelanggaran HAM berat, intitusi yang memiliki kewenangan melakukan penyelidikan adalah Komnas HAM. Selama ini kita sudah coba membedah semua hasil penyelidikan dari Komnas HAM."Bukan hanya perkara Kamisan, perkara Trisakti, tapi yang lain juga, ada enam perkara HAM berat yang akan diteliti akhirnya semua menyadari bahwa hasil penyelidikan itu hanya asumsi, opini saja, bukan bukti, proses hukum dan juga perlu bukti bukan opini."

Selanjutnya negara Indonesia adalah negara hukum sebagai perwujudan dari suatu negara hukum ini perlu memberikan jaminan perlindungan kepada warga negaranya dan juga harus memaksimalkan penanganan perkara pelanggaran HAM yang hingga saat ini belum terselesaikan dimana Kejaksaan mempunyai kendala yuridis dalam menyelesaikan pelanggaran HAM berat tersebut.

Hal-hal yang telah dibahas diatas, penulis dalam jurnal ini akan membahas mengenai "Peran Lembaga Kejaksaan Untuk Mengatasi Kendala Yuridis Dalam Penanganan Perkara Pelanggaran HAM Berat".

\section{B. Rumusan Masalah}

Berdasarkan pemaparan diatas, maka terdapat beberapa permasalahan yang akan dikaji dalam penelitian ini yakni sebagai berikut :

1. Apasajakah kasus pelanggaran HAM pada masa orde baru di Indonesia yang tidak terselesaikan?

2. Bagaimana Pengaturan Perlindungan Terhadap Hak Asasi Manusia Dalam Perspektif Hukum Nasional dan Internasional?

3. Bagaimana Lembaga Kejaksaan Dalam Penegakan Hukum menjalankan perannya Terhadap Pelanggaran Hak Asasi Manusia (HAM)

\section{Metode Penelitian}

Tipe penelitian yang digunakan dalam penulisan makalah ini adalah yuridis normatif. Metode yuridis normatif yang dimaksud adalah suatu penelitian yang didasarkan pada peraturan perundang-undangan yang berlaku dan literatur lainnya yang berkaitan dengan pokok bahasan sebagai pendukung. Penulisan jurnal ini dilakukan dengan menggunakan pendekatan undang-undang (statue approach) approach yaitu,"pendekatan yang dilakukan dengan mengidentifikasi serta membahas peraturan perundang-undangan yang berlaku berkaitan seperti UndangUndang Nomor 8 Tahun 1981 Tentang KUHAP dan KUHP dengan materi yang dibahas. Dan pendekatan secara conceptual approach yaitu suatu pendekatan yang 
diperoleh melalui literatur-literatur dan bahan bacaan lainnya sebagai teori pendukung dari pembahasan makalah ini". ${ }^{15}$

\section{Hasil Penelitian dan Pembahasan}

\section{Data dan Fakta Kasus Pelanggaran HAM}

Di tanah air, kasus pelanggaran HAM berat sempat terjadi beberapa kali dalam kurun waktu tertentu. Ada kasus pelanggaran HAM berat yang terjadi di masa Orde Baru yang menyisakan kenangan mengerikan di batin sebagian orang. Bahkan ada kasus yang hingga saat ini masih belum jelas rimbanya akan selesai atau tidak. Sebagian besar dari kasus tersebut memang diciptakan oleh sekelompok orang yang berencana melakukan aksi-aksi untuk melanggar hak orang lain entah dengan dalih apapun. ${ }^{16}$ Berikut adalah beberapa kasus pelanggaran HAM berat di Indonesia yang hingga sekarang masih menjadi topik perbincangan di tanah air.

\section{a. Tragedi G30S/PKI Tahun 1965-1966 ${ }^{17}$}

Pada tanggal 30 September 1965, terdapat beberapa nama jenderal di Indonesia yang dibunuh secara keji. Pemerintahan pada masa itu menuding Partai Komunis Indonesia sebagai dalang dari kekejaman tersebut. Seketika pemerintah langsung membubarkan PKI dan melakukan razia terhadap anggota serta simpatisan dari partai tersebut. Razia tersebut dikenal dengan Operasi Pembersihan PKI. Komnas HAM memperkirakan terdapat setidaknya 5 ribu hinga 3 juta warga yang tewas terbunuh saat itu. Ribuan warga lainnya bahkan ada yang diasingkan serta jutaan lainnya hidup dalam bayang-bayang 'cap PKI' hingga bertahun-tahun lamanya.

Menurut beberapa sumber, tragedi G30S/PKI ini dulunya ditangani oleh Kejaksaan Agung. Namun, pada tahun 2013 Kejaksaan mengembalikan berkas-berkas kasus tersebut pada Komnas HAM dengan alasan data yang diperoleh kurang lengkap. Dalam jumpa pers Senin siang, Nurcholis selaku Wakil Ketua Komnas HAM menyebutkan berdasarkan penyelidikan selama empat tahun akhirnya Komnas HAM menyimpulkan telah menemukan cukup bukti adanya dugaan kejahatan terhadap kemanusiaan pasca peristiwa G30S PKI. "Terdapat bukti permulaan yang cukup untuk menduga terjadinya kehjahatan terhadap kemanusiaan sebagai bentuk pelanggaran HAM yang berat sebagai berikut, satu pembunuhan pasal $7 \mathrm{~b}$, pemusnahan pasal $7 \mathrm{~b}$, dan pasal $9 \mathrm{~b}$

15 Peter Mahmud Marzuki, Penelitian Hukum, (Jakarta: Kencana Prenada Media Group, 2013), hlm.133-134

${ }^{16}$ Teko Neko, “Kasus Pelanggaran HAM Berat di Indonesia” dimuat dalam https://tekoneko. net/kasus-pelanggaran-ham-berat/, diakses pada tanggal 18112019.

${ }^{17}$ Ibid 
UU 26 tahun 2000 kemudian perbudakan, pengusiran, penyiksaan, perampasan kemerdekaan dan kebebasan fisik pemerkosaan dan penghilangan orang secara paksa".

Mereka yang dianggap bisa dimintai pertanggungjawabannya adalah semua pejabat dalam struktur Kopkamtib 1965-1968 dan 1970-1978 serta semua panglima militer daerah saat itu.Dengan berbagai bukti ini, sesuai undang-undang yang berlaku Komnas HAM meminta Kejaksaan Agung untuk menggunakan hasil penyelidikan Komnas HAM ini sebagai bahan untuk melakukan penyidikan. Sementara itu juru bicara Kejaksaan Agung Adi Togarisman mengatakan pihaknya akan mempelajari berkas yang dikirimkan Komnas HAM sebelum mengambil langkah hukum. "Surat dari Komnas HAM kita terima hari Jumat kemarin tanggal 20 Juli 2012. Kita melihat hasil penyelidikan yang dilakukan Komnas HAM untuk ditentukan apakah memenuhi unsur penyidikan atau tidak. Kalau memenuhi syarat ya dilakukan penyidikan, kalau tidak akan diberi petunjuk untuk melengkapinya". Kondisi ini membuat Ketua Yayasan Penelitian Korban Pembunuhan 1965/1966 Bedjo Untung khawatir kasus ini akan terbengkalai di kejaksaan agung. Ia meminta Presiden Republik Indonesia menyelesaikan kasus ini di luar jalur hukum.Meski menolak menyebutkan jumlah korban, Komnas HAM mengakui sedikitnya 32.000 orang dinyatakan hilang akibat peristiwa itu.

b. Sara $^{18}$

Di sisi lain, runtutan kasus intoleransi keagamaan di Indonesia cenderung meningkat dalam era "kebebasan berdemokrasi". Sejumlah kasus diskriminasi bernuansa suku, agama, ras, dan antargolongan (SARA) masih saja terjadi di negara berasas Pancasila ini. Bahkan, intoleransi itu berujung konflik berbasis SARA dengan korban jiwa yang tak sedikit. Misalnya, konflik antar-agama yang terjadi di Ambon, Maluku, sepanjang 1999, dan konflik etnis yang terjadi di Sampit, Kalimantan Tengah pada 2001. Polemik di Papua pasca-reformasi juga menarik untuk menjadi perhatian. Berdasarkan laporan Setara Institut pada 2016, terjadi peningkatan pelanggaran HAM di Papua yang sangat signifikan jika dibandingkan tahun sebelumnya. Sejumlah mahasiswa asal Papua yang menamakan diri Nasional Papua Solidaritas menggelar aksi masalah pelanggaran hak asasi manusia di depan Gedung Sate, Bandung, Jawa Barat, Selasa (5/6/2012). Mereka menuntut pemerintah mengusut

\footnotetext{
${ }^{18}$ Konflik dan Pelanggaran HAM, Catatan Kelam 20 Tahun Reformasi Reformasi menyimpan sejumlah noktah hitam terkait konflik dan pelanggaran HAM. Apa saja catatan kelam yang banyak di antaranya masih menanti penyelesaian itu?Rabu, 13 Juni 2018 16:44 WIB, dimuat dalam https://nasional.kompas.com/jeo/konflik-dan-pelanggaran-ham-catatan-kelam-20-tahun-reformasi, diakses pada tanggal 18112019.
} 
sejumlah perlakuan tindak kekerasan dan pelanggaran HAM yang mengorbankan warga sipil di Papua serta meminta keadilan bagi tanah Papua.

Sejumlah mahasiswa asal Papua yang menamakan diri Nasional Papua Solidaritas menggelar aksi masalah pelanggaran hak asasi manusia di depan Gedung Sate, Bandung, Jawa Barat. Mereka menuntut pemerintah mengusut sejumlah perlakuan tindak kekerasan dan pelanggaran HAM yang mengorbankan warga sipil di Papua serta meminta keadilan bagi tanah Papua.Pemerintahan Presiden Joko Widodo diakui telah memberikan perhatian lebih terkait pembangunan infrastruktur, namun mengesampingkan penegakan HAM dan penanganan konflik sosial politik.

\section{c. Pelanggaran HAM Berat 1996-199919}

Proses untuk menjatuhkan kekuasaan Presiden Soeharto dan rezim Orde Baru terbilang tidak mudah. Ada pengorbanan besar saat menyuarakan protes terhadap Soeharto kala itu.Aksi demonstrasi yang berujung mundurnya Soeharto dari jabatan presiden dapat dibilang sebagai akumulasi "kekesalan terpendam" masyarakat atas sejumlah pelanggaran hak asasi manusia (HAM) yang terjadi sepanjang dua tahun terakhir kekuasaan "The Smiling General". Namun, setelah Soeharto jatuh masih saja terjadi sejumlah catatan hitam pelanggaran HAM dalam mengatasi aksi demonstrasi mahasiswa pada 1999. Aksi represif aparat keamanan disertai penembakan menyebabkan Tragedi Semanggi I dan Semanggi II yang menewaskan sejumlah mahasiswa.

1) Penghilangan Paksa 1997 - $1998^{20}$

Rezim Orde Baru kemudian menuding Partai Rakyat Demokratik (PRD) sebagai dalang Peristiwa 27 Juli 1996. Setelah itu, terjadilah kasus penghilangan orang secara paksa periode 1997-1998. Para aktivis korban kekerasan Orde Baru mengingatkan akan korban yang hilang dan belum kembali dengan memamerkan photo-photo korban serta aksesorisnya pada 1999 silam.

Para aktivis korban kekerasan Orde Baru mengingatkan akan korban yang hilang dan belum kembali dengan memamerkan photophoto korban serta aksesorisnya pada 1999 silam.Berdasarkan laporan penyelidikan Tim Ad Hoc Komnas HAM, setidaknya 23 aktivis pro demokrasi menjadi korban. Hingga sekarang, sembilan orang dikembalikan, satu orang meninggal dunia, dan 13 orang masih hilang. 
2) Penghilangan Paksa 1997 - $1998^{21}$

Pada bulan Mei 1998, tepat 19 tahun yang lalu, telah terjadi peristiwa yang memilukan bagi perjalanan bangsa ini yang dikenal sebagai peristiwa Kerusuhan Mei 1998. Peristiwa tersebut adalah peristiwa kerusuhan bernuansa suku, agama, ras, dan antar golongan (SARA) yang terjadi pada 13-15 Mei 1998 di Jakarta dan sejumlah kota. Kerusuhan tersebut dipicu oleh tertembaknya empat mahasiswa Universitas Trisakti pada 12 Mei 1998.

Berdasarkan laporan dari Tim Gabungan Pencari Fakta (TGPF) kasus Kerusuhan Mei 1998, ditemukan beberapa variasi jumlah korban meninggal dunia dan luka-luka akibat kerusuhan tersebut. Data Tim Relewan menunjukkan sebanyak 1190 orang meninggal dunia akibat terbakar atau dibakar, 27 orang meninggal akibat senjata dan lainnya, 91 orang luka-luka. Sementara berdasarkan data Kepolisian Daerah (Polda) ditemukan 451 orang meninggal, dan korban luka-luka tidak tercatat. Selanjutnya berdasarkan data Komando Daerah (Kodam) ditemukan 463 orang meninggal termasuk aparat keamanan, 69 orang luka-luka. Kemudian berdasarkan data Pemerintah Daerah DKI Jakarta ditemukan 288 orang meninggal dunia, dan 101 orang luka-luka. Di kota-kota lain, di luar Jakarta, temuan angka korban juga bervariasi. Berdasarkan data "meninggal dunia, 131 orang luka-luka, dan 27 orang luka bakar. Sedangkan berdasarkan data Tim Relawan ditemukan sebanyak 33 orang meninggal dunia, dan 74 orang lukaluka (Temuan TGPF, Publikasi Komnas Perempuan, 1999).

Selain itu, TGPF juga menemukan adanya kekerasan seksual pada kerusuhan Mei 1998. TGPF menemukan bahwa sebagian besar kasus perkosaan adalah gang rape, di mana korban diperkosa oleh sejumlah orang secara bergantian pada waktu yang sama dan di tempat yang sama. Kebanyakan kasus perkosaan juga dilakukan di hadapan orang lain. Meskipun korban kekerasan seksual tidak semuanya berasal dari etnis Cina, namun sebagian besar kasus kekerasan seksual dalam kerusuhan Mei 1998 lalu diderita oleh perempuan dari etnis Cina. Korban kekerasan seksual ini pun bersifat lintas kelas sosial (Temuan TGPF, Publikasi Komnas Perempuan, 1999). Namun, setelah 19 tahun berlalu hingga hari ini, penyelesaian kasus Kerusuhan Mei 1998 yang dinilai sebagai kasus pelanggaran Hak Asasi Manusia (HAM) di Indonesia, masih menjadi tanda tanya. Penyelesaian secara yudisial

${ }^{21}$ Arfianto Purbolaksono, Peneliti Bidang Politik The Indonesian Institute, arfianto@theindonesianinstitute.com, Mengingat Kembali Kasus Pelanggaran HAM Kerusuhan 1998 dimuat dalam https://www.theindonesian institute. com/mengingat-kembali-kasus-pelang-garan -ham kerusuhan-1998/ diakses pada tanggal 18112019. 
hingga kini tidak pernah dilakukan terhadap pihak-pihak yang menjadi dalang dari kerusuhan tersebut.Pada Februari 2017 lalu, Jaksa Agung Muhammad Prasetyo sempat mengatakan bahwa Pemerintah memutuskan untuk menyelesaikan kasus 1998 secara non yudisial atau tanpa melalui proses peradilan. Alasannya, pencarian fakta, bukti, dan saksi atas kasus tersebut sangat sulit dilakukan. Namun, sikap Pemerintah ini dikecam oleh Human Rights Working Group (HRWG). Keputusan itu dianggap sebagai jalan pintas yang terburu-buru dan melupakan aspek keadilan yang seharusnya diterima oleh korban. Direktur Eksekutif HRWG, Muhammad Hafiz, mengatakan penyelesaian kasus pelanggaran HAM masa lalu tidak boleh serta merta diselesaikan secara non yudisial. Menurut Muhammad Hafiz sebelum ke tahap penyelesaian non yudisial seharusnya kasus tersebut diungkap dulu kebenarannya, seperti mengungkap siapa dalang kerusuhan tersebut, alasan dibalik terjadinya kerusuhan tersebut, serta bagaimana gambaran utuh peristiwanya. Semua hal tersebut harus diungkap ke publik.

3) Kasus pembunuhan Theys ${ }^{22}$

Pada 10 November 2001, Theys Hiyo Eluay dan sopirnya, Aristoteles Masoka, dikabarkan hilang dan diculik oleh orang tak dikenal. Theys merupakan Ketua Presidium Dewan Papua. Sehari kemudian, Theys ditemukan tewas di dalam mobilnya di Skouw, tak jauh dari perbatasan RI-Papua Niugini. Adapun Aristoteles Masoka sampai sekarang belum ditemukan. Kematian Theys merupakan kasus yang diduga sarat dengan motif politik dan kepentingan. Berdasarkan catatan Kontras, ada beberapa hal yang berkaitan erat dengan peristiwa pembunuhan tersebut.

I. Dokumen Departemen Dalam Negeri (Juni 2000) tentang rencana operasi pengondisian wilayah dan pengembangan jaringan komunikasi dalam menyikapi arah politik Papua untuk merdeka.

II. Fakta di lapangan menunjukkan ada peningkatan kekerasan sampai kematian Theys, dan kekerasan menurun drastis setelah pembunuhan tersebut.

Terkait kasus ini, tujuh anggota TNI dihadapkan ke pengadilan militer. Tujuh terdakwa yang disidangkan di Mahkamah Militer Tinggi III Surabaya, Rabu 5 Maret 2003. Ketujuh terdakwa itu adalah Letkol (Inf) Hartomo, Mayor (Inf) Donni Hutabarat, Kapten (Inf) Rionardo, Lettu (Inf) Agus Suprianto, Sertu Asrial, Sertu Laurensius LI, dan Praka Achmad Zulfahmi.Oditur Militer menuntut mereka

\footnotetext{
${ }^{22}$ Konflik dan Pelanggaran Ham, Op.cit
} 
hukuman 2-3 tahun penjara. Dalam sidang, Oditur Militer menyatakan para terdakwa terbukti bersalah.Namun, elemen masyarakat sipil yang tergabung dalam Solidaritas Nasional untuk Papua (SNUP) menilai proses pengadilan yang berlangsung merupakan upaya memutus rantai komando saja, bertentangan dengan prinsip imparsial, dan hanya digunakan untuk mengukuhkan impunitas aparat militer yang terlibat.Pada 2014, Komnas HAM mulai membuka kembali masalah pembunuhan Theys dan hilangnya Aristoteles Masoka.

Komnas HAM mempelajari salinan berkas dari Pengadilan Mahkamah Militer terkait kasus 13 tahun sebelumnya itu. Dari salinan berkas terungkap, para pelaku pembunuh Theys mengakui bahwa mereka sedang melaksanakan tugas negara. Hal lain yang didapatkan dari berkas tersebut, Theys disiksa terlebih dahulu sebelum dieksekusi.

4) Pembunuhan Munir ${ }^{23}$

Hingga saat ini, kasus pembunuhan aktivis HAM Munir Said Thalib masih menjadi misteri. Aktivis yang akrab disapa Cak Munir itu meninggal dunia pada 7 September 2004. Munir diracun dalam penerbangan Garuda Indonesia GA-974 dari Jakarta menuju Amsterdam, yang transit di Singapura. Saat itu, pendiri Komisi untuk Orang Hilang dan Korban Tindak Kekerasan (Kontras) itu hendak melanjutkan jenjang pendidikan di Belanda. Sejumlah korban dan keluarga korban pelanggaran hak asasi manusia (HAM) menggelar aksi solidaritas untuk aktivis pejuang HAM, Munir (almarhum), di Kantor Komisi Nasional (Komnas) HAM. Mereka meminta Komnas HAM untuk segera membentuk tim penyelidik independen guna mengusut kematian Munir. Proses peradilan telah dilakukan untuk mengadili pelaku pembunuhan Munir. Dalam kasus ini, pengadilan telah menjatuhkan vonis 14 tahun penjara terhadap Pollycarpus Budihari Priyanto, pilot Garuda yang saat itu sedang cuti tetapi ada di penerbangan yang sama dengan Munir sebagai pelaku pembunuhan Munir. Sejumlah fakta persidangan juga menyebut adanya dugaan keterlibatan petinggi Badan Intelijen Negara (BIN) dalam kasus pembunuhan ini. Namun, pada 13 Desember 2008, mantan Deputi V BIN Mayjen Purn Muchdi Purwoprandjono yang juga menjadi terdakwa dalam kasus ini divonis bebas dari segala dakwaan. Belasan tahun berselang, istri almarhum Munir, Suciwati, dan para aktivis HAM lainnya tetap meminta pemerintah mengusut tuntas kasus tersebut dan mengungkap siapa yang menjadi dalang sebenarnya. 
Menurut Suciwati, Presiden Joko Widodo pernah berjanji akan menuntaskan kasus Munir saat mengundang 22 pakar hukum dan HAM pada 22 September 2016.Pada 14 Oktober 2016, Presiden Jokowi sebutan atau panggilan untuk Joko Widodo menunjuk dan meminta Jaksa Agung segera bekerja menindaklanjuti kasus Munir berdasarkan temuan Tim Pencari Fakta (TPF) Kasus kematian Munir. Namun, hingga saat ini, Suciwati menilai pemerintah terkesan saling lempar tanggung jawab meski Komisi Informasi Pusat (KIP) mengabulkan permohonan informasi dan meminta pemerintah mengumumkan hasil investigasi TPF. Upaya Suciwati dan Kontras berlanjut pada gugatan ke KIP. Dalam sidang putusan, KIP menyatakan bahwa pemerintah diminta segera mengumumkan hasil penyelidikan TPF kasus kematian Munir seperti yang dimohonkan oleh Pemohon, yakni Kontras. Kemudian, Kementerian Sekretariat Negara (Kemensetneg) mengajukan banding atas putusan tersebut. PTUN Jakarta mengabulkan banding itu. Aktivis Jaringan Solidaritas Korban untuk Keadilan mengenang 10 Tahun Kasus Munir dalam aksi Kamisan di Istana Negara. Pegiat HAM mendesak penegak hukum untuk membuka kembali kasus Munir untuk menjerat dan menghukum auktor intelektualis di balik pembunuhan Munir. Atas Putusan PTUN, Kontras mengajukan kasasi ke MA pada 27 Februari 2017. MA memutuskan menolak kasasi tersebut.Hingga saat ini belum diketahui alasan pembunuhan Munir. Sejauh ini, dugaan yang muncul adalah pembunuhan terkait upaya Munir dalam mengungkap dan menuntut pertanggungjawaban atas sejumlah pelanggaran HAM berat di masa lalu.

\section{Pengaturan Perlindungan Terhadap Hak Asasi Manusia Dalam Perspektif Hukum Nasional dan Internasional}

Perlindungan terhadap Hak Asasi Manusia saat ini telah dilengkapi dengan perangkat hukum internasional yang tidak hanya mengatur cakupan hak dan kewajiban yang menyertai hak-hak tersebut, tetapi juga pertanggungjawaban terhadap kewajiban yang tidak dipenuhi oleh negara. Pengalaman menunjukkan bahwa perangkat hukum internasional terkait hak asasi manusia (International Human Rights Law) tidak cukup untuk secara sempurna melindungi hak asasi manusia, negara masih sering lalai dan tidaktepat dalam menjalankan kewajibannya, dan dalam beberapa kasus, pertanggungjawaban negara tidak dapat dituntut secara sempurna dengan berbagai dalih, maka dapat dipahami betapa pentingnya peranan negara dalam perlindungan hak asasi manusia, sehingga perlu bagi negara untuk dapat menjalankan perlindungan tersebut sesuai dengan standar internasional dalam 
hukum internasional. Posisi negara yang utama dalam hukum internasional telah menghasilkan juga tanggung jawab bagi negara untuk melaksanakan dan memenuhi kewajibannya. ${ }^{24}$

Dalam hukum hak asasi manusia internasional, pengertian "tanggung jawab negara" berkaitan dengan kewajiban negara dalam pemenuhan, perlindungan dan penghornatan hak asasi manusia yang diakui secara internasional. Tanggung jawab negara timbul, sebagai akibat dari pelanggaran hukum internasional oleh negara yaitu: ${ }^{25}$

a. Melakukan tindakan pelanggaran hak asasi manusia (action), dan melalaikan, tidak melakukan tindakan apapun, atau melakukan pembiaran (ommision) terhadap pelanggaran hak asasi manusia;

b. Melakukan tindakan yang merupakan pelanggaran terhadap kewajiban internasional.

Haula Adolf berpendapat bahwa : ${ }^{26}$

"Tanggung jawab negara merupakan suatu prinsip fundamental dalam hukum internasional yang bersumber dari doktrin kedaulatan dan persamaan hak antar negara. Tanggung jawab negara timbul apabila ada pelanggaran atas suatu kewajiban internasional untuk berbuat sesuatu atau tidak berbuat sesuatu baik kewajiban tersebut berdasarkan suatu perjanjian internasional maupun hukum kebiasaan internasional".

Muhammad Jailani juga berpendapat bahwa : ${ }^{27}$

"Kewajiban negara dalam memberikan perlindungan, pemajuan serta penghormatan terhadap HAM, yang menjadi concern seluruh dunia dewasa ini, merupakan konsep dunia modern setelah Perang Dunia Kedua".

24 Christanugra Philip, "Tanggung Jawab Negara Terhadap Perlindungan Hak Asasi Manusia Menurut Hukum Internasional", dimuat dalam https://ejournal.unsrat.ac.id/index.php /adminis-tratum/article/view/11293, diakses pada tanggal 27112019.

25 "Tanggungjawab Negara" Elsam, Referensi HAM, dimuat dalam http://referensi.elsam.or .id/2014/09/tanggung-jawab-negara/, diakses pada tanggal 27112019.

${ }^{26}$ Huala Adolp, Aspek-Aspek Negara dalam Hukum Internasional, Edisi Revisi, (Jakarta: PT. Raja Grafindo Persada, Jakarta, 2002) hlm. 255.

27 Muhammad Jailani, "Tanggung Jawab Negara Dalam Memberikan Perlindungan Terhadap Hak-Hak Korban Pelanggaran Ham Berat Di Indonesia" dimuat dalam https://ejournal.unisba .ac.id/index. php/ syiar_hukum/article/download/651/pdf, diakses pada tanggal 27112019 
Dasar hukum perlindungan hukum terhadap hak asasi manusia terdapat pada Pasal 1 Ayat (3) Undang-undang Dasar Tahun 1945 (UUD 1945) menyatakan bahwa : "Negara Indonesia adalah Negara Hukum". Sebagai perwujudan dari Negara Hukum (Rechtaats) adalah adanya jaminan terhadap perlindungan hak asasi manusia (HAM) dalam berbangsa dan bernegara, sejak diproklamirkan kemerdekaan bangsa Indonesia pada tahun 1945 telah menegaskan bahwa didalam Batang Tubuh Undang-Undang Dasar 1945 pada Pasal 27 - Pasal 34 memuat mengenai Hak Asasi Manusia.

Pengaturan mengenai HAM di Indonesia pada masa reformasi terutama sejak lengsernya Soeharto di zaman orde lama Presiden bersama-sama dengan DPR meratifikasi konvensi PBB yang menentang penyiksaan dan perlakuan atau penghukuman lain yang kejam, tidak manusiawi, atau merendahkan martabat manusia kedalam Undang-Undang Nomor. 5 Tahun 1998. Kemudian MPR juga menerbitkan Ketetapan MPR No. XVII/MPR/1998 tentang HAM, yang ditindaklanjuti dengan keluarnya Undang-Undang Nomor. 39 Tahun 1999 tentang Hak Asasi Manusia (HAM). Sesuai dengan tata urut perundangan di Indonesia berdasarkan Undang-Undang Nomor. 12 Tahun 2011, sebenarnya produk-produk yang telah dikeluarkan oleh pemerintah (MPR, DPR dan Presiden) yang menindaklanjuti substansi HAM dalam UUD 1945 dengan menetapkan Ketetapan MPR dan Undang-Undang tersebut sudah betul. Namun ketika kemudian MPR melakukan amandemen UndangUndang Dasar 1945 yang kedua, yaitu pada tanggal 18 Agustus Tahun 2000 dengan menambahkan bab dan pasal khusus yang berisi tentang HAM (sebagaimana tersebut dalam Bab XA pasal 28A s/d. pasal 28J), telah membuat rancu tata urut peraturan perundangan di Indonesia karena tidak sesuai dengan substansi Pasal 7 Undang-Undang Nomor 12 Tahun 2011. ${ }^{28}$

Pada Pasal 28 I ayat (4) UUD 1945 menyebutkan bahwa, "Perlindungan, pemajuan, penegakan, dan pemenuhan hak asasi manusia adalah tanggung jawab negara, terutama pemerintah" sedangkan dalam Pasal 71 UndangUndang Nomor 39 Tahun 1999 tentang HAM yang menyebutkan bahwa, "Pemerintah wajib dan bertanggung jawab menghormati, melindungi, menegakkan, dan memajukan hak asasi manusia yang diatur dalam undangundang ini, peraturan perundang-undangan lain, dan hukum internasional tentang hak asasi manusia yang diterima oleh negara Republik Indonesia”. Berdasarkan perintah Undang-Undang tersebut telah jelas bahwa pemerintah mempunyai tanggung jawab untuk menghormati, melindungi, menegakkan, dan memajukan hak asasi manusia.

Secara universal bahwa negara memikul tanggung jawab utama dalam pemajuan dan perlindungan hak asasi manusia. Tanggung jawab yang 
sedemikian tak dapat dikurangi dengan alasan-alasan politik, ekonomi maupun budaya. Sementara itu dalam kenyataan sehari-hari banyak pelanggaran hak asasi manusia dilakukan oleh negara melalui organ-organ atau aparatnya baik sipil maupun militer yang menyelewengkan kekuasaannya (abuse of power). ${ }^{29}$

Di Indonesia, berbagai bentuk ketidakadilan dan pelanggaran berat hak asasi manusia telah terjadi baik di masa orde lama maupun pada masa sekarang atau era reformasi saat ini. Pelanggaran berat tersebut telah menimbulkan penderitaan sangat berat bagi korban, keluarga dan masyarakat. Lebih dari itu, pelanggaran tersebut tidak pernah diungkap secara obyektif, dan tidak ada penyelesaian yang adil dan memadai. ${ }^{30}$

\section{Peran Lembaga Kejaksaan Dalam Penegakan Hukum Terhadap Pelanggaran Hak Asasi Manusia (HAM)}

Kinerja Kejaksaan dalam penegakan hukum atas pelanggaran hak-hak asasi manusia (khususnya pelanggaran HAM berat yang terjadi di Timor Timur pada bulan April-September 1999), hubungan antara Komisi Nasional Hak Asasi Manusia (Komnas HAM) sebagai penyelidik dengan kejaksaan selaku penyidik dan penuntut umum, serta faktor-faktor yang menghambat pelaksanaan tugas Kejaksaan dalam penegakan hukum atas pelanggaran hak asasi manusia tersebut. ${ }^{31}$

Dalam pelaksanaan penegakan hukum atas pelanggaran hak-hak asasi manusia pada masa lalu di Indonesia terdapat kendala yuridis yang dihadapi oleh lembaga Kejaksaan, antara lain : ${ }^{32}$

\section{a. Kesulitan Lembaga Kejaksaan Dalam Mencari Alat Bukti Pelanggaran HAM Yang Terjadi Di Masa Lalu}

Kesulitan pembuktian atau teknis prosedural pada kejahatan HAM merupakan sesuatu yang sudah lazim terjadi pada kasus-kasus pelanggaran HAM karena kejahatan itu bukan kejahatan biasa (konvensional) tetapi kejahatan politik atau kejahatan dengan motif politik dari sebuah rezim yang dilakukan secara terencana, rahasia dan

29 Sugeng Bahagijo dan Asmara Nababan, Hak Asasi Manusi: Tanggung Jawab Negara Peran Institusi Nasional dan Masyarakat, KOMNAS HAM, Jakarta, 1999. hlm. 8

30 Ibid

31 Aulia Rosa Nasution, "Penyelesaian Kasus Pelanggaran HAM Berat melalui Pengadilan Nasional dan Internasional serta Komisi Kebenaran dan Rekonsiliasi", https://www.research gate.net/publication/327180172__ Penyelesaian_Kasus_Pelanggaran__HAM_Berat__melalui_ Pengadilan_Nasional_dan_Internasional_serta_Komisi_Kebenaran_dan_Rekonsiliasi, diakses pada tanggal 27112019.

32 Ibid 
sistematis, termasuk dalam menghilangkan jejak kejahatannya. Selain itu lamanya jarak waktu antara terjadinya peristiwa denagn pengusutan berakibat pada sulitnya mencari alat bukti yang rusak, hilang, daya ingat saksi yang berkurang atau bahkan hilang, dihilangkan atau meninggal dunia.

Sementara itu kendala politik berupa tekanan, intimidasi, pengaruh dan ancaman kekuatan politik rezim lama menjadi masalah yang umumnya akan mempengaruhi rezim baru. Rezim pengganti akan dihantui oleh ketakutan pada militer yang akan melakukan kudeta, dan mengembalikan ke rezim otoritarian baru atau melakukan tindakan tindakan liar yang dimaksudkan untuk mengacaukan tatanan sosial, ekonomi, hukum dan politik yang sedang dibangun. Potensi kekuatan rezim lama untuk mencegah rezim baru untuk dapat melakukan langkahlangkah hukum mengusut kejahatan HAM yang pernah mereka lakukan tidak dapat diabaikan karena kekuatan mereka terletak pada pengaruh politik mereka yang kuat. ${ }^{33}$

Pada Parlemen sebagaimana yang pernah terjadi, pada periode 19992004, Golkar dan TNI-Polri masih merupakan kekuatan politik riil di Parlemen karena dengan 120 kursi, ditambah 62 kursi dari utusan daerah, ditambah 38 kursi TNI Polri jelas memiliki pengaruh politik yang signifikan dalam parlemen.

Sementara itu, unsur PNS dan keluarga besarnya sejak Pemilu 1971 menjadi kekuatan besar bagi Golkar dan ini diakui oleh Akbar Tanjung sebagai salah satu penentu kemenangan Golkar pada pemilu-pemilu Orde Baru. Kekuatan rezim Orde Lama tidak hanya terletak pada pengaruh politik dan eksekutif (birokrasi sipil) atau lembaga yudikatif tetapi juga pada kekuatan ekonomi dan ideologis. Melalui dua unsur utama pendukung Status Quo Orde Baru tersebut upaya blokade atau penghambatan terhadap penyelesaian hukum atas kasus-kasus masa lalu bisa mereka lakukan dengan pelbagai cara, mulai pemandulan aturan hukum material dan formal, mengacaukan opini publik dengan memanipulasi informasi melalui media massa, sampai pada tindakantindakan fisik berupa penculikan, pembunuhan atau kekacauan.

Kegagalan pengadilan HAM ad hoc meminta pertanggungjawaban hukum pidana pelanggaran HAM, lambannya pembentukan UU Komisi Kebenaran dan Rekonsiliasi (KKR), yang kemudian berujung pembatalan UU tersebut oleh MK merupakan keberhasilan rezim lama dalam mengamankan kejahatannya. Rangkaian kegagalan itu sekaligus kegagalan politik hukum HAM transisional yang dimasudkan 
mengantarkan rezim baru menuju negara hukum demokratis di atas terbangunnya politik hukum HAM bagi penghormatan, perlindungan dan penegakan HAM. ${ }^{34}$

b. Pelanggaran HAM Yang Terjadi Di Indonesia Pada Masa Lalu Sebelum Undang-Undang Nomor 26 Tahun 2000 Tentang Pengadilan HAM Diberlakukan

Komitmen pemerintah RI terhadap penegakan HAM tidak hanya ditunjukkan dengan pengesahan Undang-Undang tentang HAM, yaitu Undang-Undang Nomor. 39 tahun 1999 dan Undang-Undang Nomor 26 Tahun 2000 Tentang Pengadilan HAM, pembentukan Kantor Menteri Negara Urusan HAM yang kemudian digabung dengan Departemen Hukum dan Perundang-undangan menjadi Departemen Kehakiman dan HAM, penambahan pasal-pasal khusus tentang HAM dalam Amandemen UUD 195, penerbitan Inpres tentang pengarusutamaan gender dalam pembangunan nasional, pengesahan UU tentang Pengadilan HAM.

Pada tahun 2001 Indonesia juga menandatangani dua Protokol Hak Anak yaitu protokol yang terkait dengan larangan perdagangan, prostitusi dan pornografi anak serta protokol yang terkait dengan keterlibatan anak dalam konflik bersenjata. Menyusul kemudian pada tahun yang sama pemerintah membuat beberapa pengesahan Undang-Undang diantaranya tentang perlindungan anak, pengesahan tentang penghapusan kekerasan dalam rumah tangga dan penerbitan keppress tentang Rencana Aksi Nasional (RAN) HAM Indonesia tahun 2004-2009. ${ }^{35}$

Politik hukum HAM terus berlanjut dengan diberlakukannya UndangUndang Nomor. 39 Tahun 1999 tentang HAM sebagai implementasi TAP XVII/MPR/1998. Selanjutnya di era pemerintahan Gus Dur, pemerintah mengeluarkan Undang-Undang Nomor. 26 tahun 2000 tentang Pengadilan HAM yang memuat ketentuan prinsip retroaktif sehingga memungkikan dilakukannya proses hukum terhadap berbagai kasus pelanggaran berat HAM yang terjadi pada masa lalu. Atas dasar itulah maka pemerintahan Gus Dur membentuk Pengadilan HAM ad hoc di Jakarta, Surabaya, Medan dan Makassar melalui Keppres No. 31 Tahun 2001 untuk mengadili pelanggaran HAM yang terjadi di Timor-Timur dan Tanjung Priok. ${ }^{36}$ Kebijakan hukum HAM pemerintahan era reformasi untuk menyelesaikan pelanggaran HAM pada masa lalu merupakan salah satu kemajuan dalam perkembangan HAM di Indonesia sekaligus menjadi

${ }^{34}$ Ibid

35 A. Ubaedillah \& Abdul Rozak, "Pendidikan Kewarganegaraan, Demokrasi , Hak Asasi Manusia dan Masyarakat Madani, Indonesian Center for Civic Education (ICCE)", (Jakarta: Kencana Prenada Media, 2008), hlm 18.

${ }^{36}$ Aulia Rosa Nasution, Op.cit 
langkah politik hukum HAM yang strategis. Bagi kelompok pro demokrasi, penyelesaian melalui mekanisme hukum dalam bentuk mengadili pelaku merupakan pilihan yang tepat untuk menghilangkan kekebalan hukum (impunity) atau "perlakuan istimewa" terhadap para pemimpin negara dan aparat negara tingkat tinggi yang melanggar HAM di masa lalu. ${ }^{37}$

Pelanggaran HAM Berat masa lalu sebagaimana sudah dipaparkan sebelumnya, diproses secara hukum melalui Pengadilan HAM berdasarkan Undang-Undang Nomor 26 Tahun 2000. Menurut Pasal 18 ayat (1) Undang-Undang Nomor 26 Tahun 2000 Tentang Pengadilan HAM, penyelidikan atas pelanggaran HAM berat dilakukan oleh Komisi Nasional Hak Asasi Manusia (Komnas HAM). Komnas HAM dalam melaksanakan tugasnya, berwenang menerimalaporan atau pengaduan seseorang atau kelompok orang tentang terjadinya pelanggaran HAM yang berat Pasal 19 ayat (1) huruf b Undang-Undang Nomor 26 Tahun 2000 Tentang Pengadilan HAM). Sedangkan, untuk penyidikan dan penuntutan atas pelanggaran HAM berat dilakukan oleh Jaksa Agung Pasal 21 ayat (1) jo. Pasal 23 ayat (1) Undang-Undang Nomor 26 Tahun 2000 Tentang Pengadilan HAM.

Pasal 43 Undang-Undang Nomor 26 Tahun 2000 Tentang Pengadilan HAM hanya berisi tentang kewenangan Pengadilan HAM ad hoc yang memeriksa, mengadili dan memutus pelanggaran HAM berat masa lalu, siapa yang memiliki kewenangan untuk membentuk dan ruang lingkup dari Pengadilan HAM ad hoc itu sendiri. Tidak ada ketentuan yang menyebutkan atau mendefinisikan mengenai Pengadilan HAM Ad hoc dan kapan terbentuknya, tidak seperti apa yang dimaksud dengan Pengadilan HAM yang oleh Pasal 1 ayat (3) Undang-Undang Nomor 26 Tahun 2000 Tentang Pengadilan HAM ditentukan bahwa yang dimaksud Pengadilan HAM adalah pengadilan khusus terhadap kasus pelanggaran HAM berat. Jika ketentuan yang ada dalam Pasal 1 ayat (3) dikaitkan dengan Pasal 43 ayat (1) yang menyebutkan bahwa pelanggaran HAM berat yang terjadi sebelum diundangkannya Undang-Undang Nomor 26 Tahun 2000 Tentang Pengadilan HAM diperiksa dan diputus oleh Pengadilan HAM ad hoc, penulis berpendapat bahwa apa yang dimaksud dengan Pengadilan HAM ad hoc adalah Pengadilan HAM khusus yang memeriksa dan memutus perkara pelanggaran HAM berat, yang terjadi sebelum 
diundangkannya Undang-Undang Nomor 26 Tahun 2000 Tentang Pengadilan HAM pada tanggal 23 November $2000 .^{38}$

Pasal 43 ayat (2) Undang-Undang Nomor 26 Tahun 2000 Tentang Pengadilan HAM menentukan bahwa pembentukan Pengadilan HAM ad hoc dibentuk atas usul DPR RI berdasarkan peristiwa tertentu dengan Keppres. Penjelasan Pasal 43 ayat (2) Undang-Undang Nomor 26 Tahun 2000 Tentang Pengadilan HAM menyebutkan bahwa dalam hal DPR RI mengusulkan dibentuknya Pengadilan HAM ad hoc, DPR RI berdasarkan pada dugaan telah terjadinya pelanggaran HAM berat yang dibatasi pada locus dan tempus delicti tertentu yang terjadi sebelum diundangkanya Undang-Undang Nomor 26 Tahun 2000 Tentang Pengadilan HAM. ${ }^{39}$

Jaksa Agung yang berpendapat bahwa pembentukan Pengadilan HAM ad hoc harus dilakukan sebelum penyelidikan dan penyidikan terhadap pelanggaran HAM yang berat dimulai, seperti kasus penculikan aktivis tahun 1997/1998, di mana Jaksa Agung menolak untuk menindaklanjuti hasil penyelidikan dari Komnas HAM karena beralasan belum terbentuknya Pengadilan HAM ad hoc. Pengalaman Pengadilan HAM ad hoc untuk kasus pelanggaran HAM berat di Timor-Timur menunjukan bahwa mekanismenya adalah Komnas HAM melakukan penyelidikan lalu hasilnya diserahkan ke Kejaksaan Agung, yang kemudian Kejaksaan Agung melakukan penyidikan. Hasil Penyidikan diserahkan ke Presiden. Presiden mengirimkan surat kepada DPR dan diikuti dengan dikeluarkannya rekomendasi oleh DPR mengeluarkan rekomendasi. Setelah rekomendasi dikeluarkan, Presiden mengeluarkan Keppres mengenai pembentukan Pengadilan HAM ad hoc. ${ }^{40}$

Selanjutnya menurut Zainal Abidin berpendapat bahwa :

"Dalam perpanjangan penahanan untuk kepentingan penuntutuan atau izin persetujuan penyitaan dalam perkara pelanggaran HAM berat yang terjadi sebelum berlakunya Undang-Undang Nomor 26 Tahun 2000 Tentang Pengadilan HAM harus diajukan ke Pengadilan HAM ad hoc, bukan ke Pengadilan HAM. Tanggapan atas penolakan dan perpanjangan penahanan yaitu, dalam UU Pengadilan HAM tidak adanya perbedaan antara penyidik pelanggaran HAM yang berat yang terjadi sebelum

38 Satya Kumarajati, "Analisis Pasal 43 Undang-Undang Pengadilan Hak Asasi Manusia dalam Kasus Penghilangan Orang secara Paksa Tahun 1997/1998", dimuat dalam https://jurnal. unej.ac.id/index.php/ eJLH/article/download/6816/5384/8 Mei 2018, diakses pada tanggal 28112019.

${ }^{39}$ Ibid

40 Zainal Abidin, Pengadilan Hak Asasi Manusia di Indonesia: Regulasi, Penerapan dan Perkembangannya, (Jakarta: Elsam, 2007), hlm. 8-9. 
dengan sesudah berlakunya Undang-Undang Nomor 26 Tahun 2000 Tentang Pengadilan HAM yang dilakukan oleh Kejaksan Agung, berbeda dengan pengadilan yang mempunyai wewenang untuk memberikan dan memutus pelanggaran HAM berat yang terjadi sebelum dan sesudah berlakunya Undang-Undang Nomor 26 Tahun 2000 Tentang Pengadilan HAM". ${ }^{41}$

Terkait dengan penuntutan peristiwa pelanggaran HAM berat yang terjadi sebelum berlakunya Undang-Undang Nomor 26 Tahun 2000 Tentang Pengadilan HAM, penentuan peristiwa tersebut harus dilanjutkan pemeriksaan hukumnya melalui pengadilan HAM Ad Hoc, bergantung kepada DPR. Namun, ketentuan pembentukan Pengadilan HAM Ad Hoc melalui usul DPR pernah dimohonkan pengujian materi kepada Mahkamah Konstitusi oleh Eurico Guterres. Hasilnya, melalui Putusan MK No.18/PUU-V/2007 Mahkamah Konstitusi menyatakan bahwa penjelasan Pasal 43 ayat (2) Undang-Undang Nomor 26 Tahun 2000 Tentang Pengadilan HAM sepanjang mengenai kata "dugaan" bertentangan dengan Undang-Undang Dasar 1945 dan tidak memiliki kekuatan hukum mengikat.

Kata 'dugaan' dalam penjelasan Pasal 43 ayat (2) Undang-Undang Nomor 26 Tahun 2000 Tentang Pengadilan HAM dapat menimbulkan ketidakpastian hukum, maka dengan adanya putusan MKNo. 18/PUUV/2007, DPR tidak boleh serta merta menduga sendiri tanpa memperoleh hasil penyelidikan dan penyidikan dari Komnas HAM dan Kejaksaan Agung.Komnas HAM merupakan lembaga yang mempunyai kewenangan untuk menyelidiki peristiwa yang diduga merupakan pelanggaran HAM berat.

Kewenangan penyelidikan untuk peristiwa semacam itu hanya dimiliki oleh Komnas HAM. Komnas HAM juga dapat menyelidiki dugaan terjadinya pelanggaran HAM yang berat tanpa adanya laporan atau pengaduan. Komnas HAM dapat langsung melakukan penyeliidkan atau melalui mekanisme tertentu menyelidiki dugaan terjadinya pelanggaran HAM yang berat. Kewenangan ini juga tetap dapat dilakukan meskipun perkara yang diselidiki telah ditangani oleh mekanisme lain dari sistem peradilan.Jika berdasarkan hasil penyelidikan Komnas HAM ditemukan bukti-bukti permulaan yangcukup untuk menyatkan bahwa peristiwa yang berdasarkan sifat dan lingkupnya dapat didugasebagai sebuah pelanggaran HAM yang berat maka peristiwa itu dapat diajukan ke pengadilanHAM sesuai ketentuan yang berlaku. ${ }^{42}$

${ }^{41}$ Satya Kumarajati, Op.cit

${ }^{42}$ Nunik Nurhayati, "Quo Vadis Perlindungan Hak Asasi Manusia Dalam Penyelesaian Pelanggaran HAM Berat Masa Lalu Melalui Jalur Non Yudisial", dimuat dalam 
Kemudian dalam penerapan Pasal 43 ayat (1) Undang-Undang Nomor 26 Tahun 2000 Tentang Pengadilan HAM diajukan permohonan judicial review ke Mahkamah Konstitusi (MK) oleh Abilio Jose Osorio Soares, mantan Gubernur Timor Timur pada waktu itu (tahun 2004). Asas retroaktif ini dianggap bertentangan dengan asas legalitas yang diatur dalam Pasal 1 Kitab Undang-Undang Hukum Pidana (KUHP) dan juga bertentangan dengan ketentuan konstitusi Pasal 28I ayat (1) UndangUndang Dasar 1945.Pasal 1 ayat (1) KUHP :Suatu perbuatan tidak dapat dipidana, kecuali berdasarkankekuatan ketentuan perundang-undangan pidana yang telah ada.Pasal 28I Ayat (1) UUD 1945: Hak untuk hidup, hak untuk tidak disiksa, hak kemerdekaanpikiran dan hati nurani, hak beragama, hak untuk tidak diperbudak, hak untuk diakuisebagai pribadi di hadapan hukum dan hak untuk tidak dituntut atas dasar hukum yangberlaku surut adalah hak asasi manusia yang tidak dapat dikurangi dalam keadaan apapun. Meski demikian, MK kemudian menolak permohonan judicial review Abilio Osario Soares terhadap Pasal 43 ayat (1) UU Pengadilan HAM melalui putusan MK No. 065/PUUII/2004.Keberadaan Pengadilan HAM ad hoc menimbulkan perdebatan karena merupakan salah satubentuk pengesampingan asas non-retroaktif. Namun demikian, melalui Putusan MK No. 065/PUU-II/2004, Pengadilan HAM ad hoc dinyatakan tidak bertentangan dengan UUD 1945. Pengadilan tersebut merupakan pengesampingan terhadap asas nonretroaktif yang dilakukan dengan sangat hati-hati. hal tersebut tertuang dalam pertimbangan hukum Putusan MK tersebut sebagai berikut: ${ }^{43}$

1) Pembentukannya hanya terhadap peristiwa-peristiwa tertentu dengan locus delicti dan tempus delicti yang terbatas, bukan untuk semua peristiwa secara umum; dan

2) Pengadilan HAM ad hoc hanya dapat dibentuk atas usul DPR karena menurut UUD 1945.

DPR adalah representasi rakyat Indonesia, yang berarti bahwa pada dasarnya rakyatlah yang menentukan kapan pelanggaran HAM yang berat sebelum pembentukan Undang-Undang Nomor 26 Tahun 2000 Tentang Pengadilan HAM telah terjadi yang penyelesaiannya membutuhkan pembentukan Pengadilan HAM ad hoc. Perdebatan penerapan asas retroaktif memang bukan hal yang baru. Sebelumnya, penerapan asas retroaktif telah dipertimbangkan oleh majelis hakim ad hoc pengadilan HAM untuk beberapa terdakwa kasus Timor Timur dalam putusan sela.

journals.ums.ac.id/index.php/ jurisprudence/ article/download/3012/1954, diakses pada tanggal 28112019.

${ }^{43}$ Satya Kumarajati, Op.cit 
Di mana dalam putusan selatersebut disebutkan asas retroaktif digunakan berdasarkan kajian terhadap praktik pengadilan pidana internasional yang mengesampingkan asas non retroaktif demi tegaknya keadilan. Kajian tersebut antara lain mengacu pada praktik negara-negara sejak pengadilan penjahatperang di Nuremberg dan Tokyo, pengadilan internasional ad hoc untuk Yugoslavia danRwanda (ICTY dan ICTR), dan kasus Adolf Eichman di pengadilan distrik Yerusalem. Selain itu, pertimbangan majelis hakim ad hoc saat itu antara lain adalah kejahatan pelanggaran HAM berat merupakan extra ordinary crime dan berdampak secara luas oleh karena itu asas retroaktif dapat diberlakukan dengan adanya Amandemen UUD 1945 Pasal 28 J ayat (2).

Dapat disimpulkan bahwa peristiwa pelanggaran HAM berat yang terjadi sebelum berlakunya Undang-Undang Nomor 26 Tahun 2000 Tentang Pengadilan HAM tetap dapat diusut, diperiksa, dan diadili melalui Pengadilan HAM Ad Hoc. ${ }^{44}$ Namun, pembentukan Pengadilan HAM Ad Hoc ini diajukan oleh DPR setelah mendapathasil penyelidikan dan penyidikan dari Komnas HAM dan Kejaksaan Agung.

\section{Penutup}

Berdasarkan uraian di atas, peneliti dapat menarik kesimpulan yang merupakan jawaban dari pokok masalah dalam penulisan makalah ini, yaitu terdapat kendala yuridis yang dihadapi oleh Lembaga Kejaksaan dalam upaya penanganan pelanggaran HAM berat, yaitu : 1. Kesulitan Lembaga Kejaksaan Dalam Mencari Alat Bukti Pelanggaran HAM Yang Terjadi Di Masa Lalu; 2. Pelanggaran HAM Yang Terjadi Di Indonesia Pada Masa Lalu Sebelum UndangUndang Nomor 26 Tahun 2000 Tentang Pengadilan HAM Diberlakukan.

Pemerintah bersama dengan Kejaksaan sebagai lembaga penegak hukum perlu mengoptimalkan Komisi Kebenaran dan Rekonsiliasi (KKR) dalam upaya menyelesaikan pelanggaran HAM berat di Indonesia yang sampai dengan saat ini belum terselesaikan.

\section{DAFTAR PUSTAKA}

Buku:

A. Ubaedillah \& Abdul Rozak, (2008), Pendidikan Kewarganegaraan, Demokrasi , Hak Asasi Manusia dan Masyarakat Madani, Indonesian Center for Civic Education (ICCE), Jakarta: Kencana Prenada Media

${ }^{44}$ Ibid 
Chainur Arrasjid, (2000), Dasar-dasar Ilmu Hukum, Sinar Grafika,

Zainal Abidin, (2007), Pengadilan Hak Asasi Manusia di Indonesia: Regulasi, Penerapan dan Perkembangannya, Jakarta : Elsam

\section{Internet :}

Arfianto Purbolaksono, Peneliti Bidang Politik The Indonesian Institute, arfianto@theindonesianinstitute.com, Mengingat Kembali Kasus Pelanggaran HAM Kerusuhan 1998 dimuat dalam https://www.theindonesianinstitute.com/ mengingat-kembali-kasus-pelang-garan -ham -kerusuhan-1998/.

Aulia Rosa Nasution, "Penyelesaian Kasus Pelanggaran HAM Berat melalui Pengadilan Nasional dan Internasional serta Komisi Kebenaran dan Rekonsiliasi", https://www.research gate.net/publication/327180172_ Penyelesaian_Kasus_ Pelanggaran_HAM_Berat_melalui_Pengadilan_ Nasional_dan_Internasional_ serta_Komisi_Kebenaran_dan_Rekonsilisi

Christanugra Philip, "Tanggung Jawab Negara Terhadap Perlindungan Hak Asasi Manusia Menurut Hukum Internasional", dimuat dalam https:// ejournal.unsrat.ac.id/index.php/adminis-tratum/article/view/11293

Eko Hidayat, "Perlindungan Hak Asasi Manusia Dalam Negara Hukum Indonesia"dimuat dalam https://media.neliti.com/media/publications/ 56534-IDnone.pdf.

Fazlur Rahman, Muhammad Ashri, Trifenny Widayanti, Analisis Yuridis Pelanggaran Hak Asasi Manusia (Ham) Di Indonesia (Studi Kasus Di Mesuji Sumatra Selatan), dimuat dalam http://repository.unhas.ac.id/ bitstream/ handle/123456789/4845/JURNAL\%20FAZ.pdf.

https://nasional.kompas.com/jeo/konflik-dan-pelanggaran-ham-catatan-kelam-20tahun-reformasi.

http://referensi.elsam.or .id/2014/09/tanggung-jawab-negara/.

Huala Adolp, Aspek-Aspek Negara dalam Hukum Internasional, Edisi Revisi, PT. Raja Grafindo

Mahadeva Wahy, "Ungkap Pelanggaran HAM, Kejaksaan Hadapi Kendala Yuridis", dimuat dalam https://www.cendananews.com/2018/06/ ungkap-pelanggaran-hamkejaksaan-hadapi-kendala-yuridis.html.

Mohammad Wildasite, "Pengertian HAM Atau Hak Asasi Manusia (Human Rights)" dimuat dalam https://mohammadwildasite.wordpress.com/hak-asasi-manusia. 
Muhammad Jailani, "Tanggung Jawab Negara Dalam Memberikan Perlindungan Terhadap Hak-Hak Korban Pelanggaran Ham Berat Di Indonesia" dimuat dalam https://ejournal.unisba .ac.id/index.php/ syiar_hukum/ article/download/651/pdf

Nunik Nurhayati, "Quo Vadis Perlindungan Hak Asasi Manusia Dalam Penyelesaian Pelanggaran HAM Berat Masa Lalu Melalui Jalur Non Yudisial", dimuat dalam journals.ums.ac.id/index.php/jurisprudence/ article/download/3012/1954

Rudi Pradisetia Sudirdja, "Implementasi Penegakan dan Perlindungan Hak Asasi Manusia Dalam Konteks Negara Hukum", Negara Republik Indonesia" dimuat dalam http://www.rudipradisetia.com/2010/06/ implementasi-penegakan-danperlindungan_21.html.

Satya Kumarajati, "Analisis Pasal 43 Undang-Undang Pengadilan Hak Asasi Manusia dalam Kasus Penghilangan Orang secara Paksa Tahun 1997/1998", dimuat dalam https://jurnal. unej.ac.id/index.php/eJLH/ article/download/6816/5384/8 Mei 2018,

Sugeng Bahagijo dan Asmara Nababan, Hak Asasi Manusi: Tanggung Jawab Negara Peran Institusi Nasional dan Masyarakat, KOMNAS HAM, Jakarta, 1999.

Teko Neko, "Kasus Pelanggaran HAM Berat di Indonesia" dimuat dalam https://tekoneko. net/kasus-pelanggaran-ham-berat/. 